\title{
A Non-Cantonese Speaker's “Growing Pains" at a Foreign Language Institute in Guangzhou: An Autoethnographic Approach to Bilingualism/Trilingualism
}

\author{
Hui Huang \\ School of English and Education, Guangdong University of Foreign Studies, Guangzhou, China \\ Email: bettyhuanghui@sina.com.cn
}

Received 16 March 2016; accepted 17 April 2016; published 20 April 2016

Copyright (C) 2016 by author and Scientific Research Publishing Inc.

This work is licensed under the Creative Commons Attribution International License (CC BY).

http://creativecommons.org/licenses/by/4.0/

(c) () Open Access

\begin{abstract}
The present study focuses on an individual's living experience in a trilingual culture, with some of her peers' stories as support. The autoethnographic study hopes to find how a non-native has settled down in a Cantonese-speaking city linguistically, especially when she is a learner and teacher of English at the same time.
\end{abstract}

Keywords

Cantonese, Autoethnographic, Bilingualism/Trilingualism

\section{Introduction}

Guangzhou, with an older name Canton, is a major Cantonese speaking city in Guangdong, China. But compared with Hong Kong, putonghua is much more widely spoken and heard here at the same time. Besides the Chinese dialects, English is used sometimes somewhere, as Guangzhou is being built up to be an international city, with a foreign resident population of $60,000^{1}$. Therefore Guangzhou to some extent is a place where trilingualism can be found and is worth exploring.

The present study focuses on an individual's living experience in this trilingual culture, with some of her peers' stories as support. The study hopes to find how a non-native has settled down in a Cantonese-speaking city linguistically, especially when she is a learner and teacher of English at the same time.

The major methodology used is autoethnography. This approach is adopted in works such as Grace Feuer${ }^{1}$ http://www.gzonline.net/Channel/content/2009/200910/20091015/14661.html.

How to cite this paper: Huang, H. (2016). A Non-Cantonese Speaker's "Growing Pains" at a Foreign Language Institute in Guangzhou: An Autoethnographic Approach to Bilingualism/Trilingualism. Open Journal of Modern Linguistics, 6, 127-130. 
verger's (2007) recent book Teaching, Learning and Other Miracles which explores teaching and learning in schools as a sacred life journey. As Carolyn and Bochner (2000) advocate it, the main advantages of this approach, are that it makes the researcher's own experience a topic of investigation in its own right rather than seeming "as if they are written from nowhere by nobody" (p. 734), it displays multiple layers of consciousness, connecting the personal to the cultural, and autoethnographers "ask their readers to feel the truth of their stories and to become coparticipants, engaging the storyline morally, emotionally, aesthetically, and intellectually” (p. 745).

The presentation of the "growing pains" of the author is made up of life history and anecdotes of different times.

\section{The Language Background of the Author When She Was Eighteen}

\subsection{Mother Tongue}

I have lived in different places in this country and each has a unique sub-culture and dialect. I was born in Jinan, a northern city where people speak Shandong dialect. I did not stay there for long (just a couple of months), and I do not speak that dialect. The dialect I am more familiar with is quite similar to mandarin but with different tones. That is because not long after I was born I was taken to Nanjing where I lived for eighteen years. It is south of Shandong and north of Zhejiang, so it is neither a typical northern nor southern city. Many of the population are descendants of people coming from the North (me included), yet they speak differently from the northerners. The tones are changed, and it might sound a little bit funny to a person from elsewhere. However, thanks to the dialect which is actually one variety of mandarin, people in Nanjing speak quite good putonghua if they have to (in formal settings like an interview or class), compared with people from southern provinces especially. My rating for putonghua, for example, is Class A (done in 2003), which is just next to that of a broadcaster (They need an $\mathrm{A}+$ ). So although I speak mainly Nanjing dialect when with family and friends, I consider myself to be a putonghua speaker (My putonghua is a little accented in effect, but that may hardly be detected by a Southerner).

\subsection{English}

By the age of eighteen, I have learned English for at least eight years, two years at elementary school and six years at secondary school. The secondary school I attended was called a "foreign languages school" and was not very different from an ordinary middle school (although a lot of people outside of the school thought it was). The only difference was the language curriculum. We had more English textbooks than students in most other schools and smaller English class size (25 people or so compared to around 50 in other schools). Besides the Chinese teachers every year there would be a native speaker of English coming to teach my class on a weekly basis, which was quite special and a privilege to a middle school at that time (in the 1990s). In addition to English, French, German and Japanese were also taught in that school as first foreign languages, to a much smaller group of students though. And thanks to that, I had opportunity to learn some simple French at a second foreign language course.

\section{My Ten-Year Stay in Guangzhou}

\subsection{No Expectation of Cantonese and Confidence in Putonghua}

Before I came to Guangzhou, I know little about Guangdong and Guangzhou, including the dialect(s). A girl, after she knew I was going to Guangzhou for college, asked me whether it could be possible that I would not understand the locals' talking. I was a little bit sneering at her worry, and I replied, that is quite impossible because people in college all speak putonghua. That was the impression I got from the area where I was from: people in institutions generally speak putonghua rather than Nanjing dialect, which is widely used in informal setting, like at home or between friends.

A few days after the registration in college, me and the others who were from the same secondary school went to a restaurant. We complained to the waitress about the airconditioner, and she explained something in Cantonese. I then said confindently "Please speak putonghua". At that time I did not realize that Cantonese was the norm in this region, not putonghua. 


\subsection{Feeling Ashamed and Uncomfortable}

When I was a first year student, one morning I was going downstairs between classes, and two girls (might from other schools) stopped me and ask in Cantonese where "the second teaching building was". I did not know what they were asking of course and I said something like "What are you saying?" And they soon realized I was not a Cantonese speaker and gave a snort of laughter to each other. They still looked friendly and polite, but I was hurt by that laughter.

Still in the first year at college, I entered an oral English contest organized by Guangdong Radio Station. The contestants had a brief talk while waiting. A school girl, quite nice-looking and polite, asked me something in Cantonese, and because I did not know what she had said, I could only nodded my head without saying anything. And the girl might be puzzled by my "weird" reaction, and a few seconds later, she realized I did not speak Cantonese. That few seconds made me really uncomfortable.

\subsection{Cantonese in Class}

As we were English majors, English was the major working language in class. But sometimes Cantonese could be heard. When teachers explained something, they might use Cantonese. Once in English pronunciation class, the teacher made an analogy by quoting an Cantonese saying. The Cantonese-speaking students nodded when they heard this, but we did not know what the teacher was talking about. Sometimes the teachers said something in Cantonese to add some fun (I suppose so). A teacher teaching listening skills once began her class by saying "Hoai Gayee Ah" meaning turn on the machine. One Cantonese-speaking student gave a loud response "Hoai Dswo" as he had turned it on. In the above cases when part of the in-class interaction were done in Cantonese, few non-Cantonese speakers were involved. They might even give negative comments when teachers produced some Cantonese in class, as one classmate of mine once said half jokingly "how dare she (a teacher) speak Cantonese in class".

\subsection{Another "Language" to Be Coped with}

The overwhelming use of Cantonese "forced" us to learn this particular Chinese dialect. I bought a Cantonese course book, and listened to the recording some twenty days during the second winter vacation. And I tried occasionally to produce some words in Cantonese to dormmates and classmates, and they might point out that I should have uttered the words differently, as regards vowel, tone or shape of mouth. This same thing was reported by one of my peers, as she wrote, "when I was free as a freshman, I followed a Practical Cantonese Course by listening, and I acquired some basic rules of pronunciation, ... When learning, the roommate from Guangzhou could not tolerate my bad Cantonese and so she often gave me guidance and that helped me a lot.” What is interesting is both the author and her peer rely, to some extent, on tape recorder when learning Cantonese. I suppose the reason might be that as English majors they followed the same method as learning English.

\subsection{Speaking to Cantonese Students when I Am a Teacher of English}

I found a teaching job in the same foreign languages institute when I left the postgraduate school. By the time I had been in Guangzhou for six years. The majority of the students are still from Guangdong Province. Once some of them asked me in class in Cantonese “Do you speak or know Cantonese?” and I replied immediately in the same dialect "I don't know” with some pride. The students were a little stunned without proceeding with the conversation. I think many Cantonese students would be surprised when they suddenly find their teacher who is from elsewhere other than Guangdong knows some Cantonese, and the second thing they may express is their welcome. One of them said, “we'll try to immerse you in the Cantonese context!”

I do not only speak a little Cantonese in informal conversations, but also I may have my students say some Cantonese while I am teaching. This often occurs when I am introducing some borrowings in English. When I said such words as wok, ketch-up were originated in Cantonese, the students looked amazed by saying "Oow!” (a Chinese expression for finding some truth or come to realize something). I even allow students in my English class to speak Cantonese to each other sometimes as I think I really cannot completely stop them expressing themselves by using a more convenient way (I did not of course, give such instruction explicitly as "Please speak Cantonese"; I just seldom interrupt their talking.). 


\subsection{A More Active Learner and Confident Speaker}

Now when speaking with my Cantonese roommates or colleagues, I may try more often to use Cantonese. There are still problems with pronunciation though, for my utterance may be implicitly corrected by native speakers. However, I started to feel that I enjoy some privilege over those who cannot speak Cantonese at all. When a teacher from Macao asked a question in putonghua with some difficulty to a travel agent in Xi'an, I repeated a key word for both of them for I knew what the Cantonese-speaking woman meant and found the travel agent was in puzzle. The same friend mentioned above reported that, she felt proud when her Cantonese songs were considered "authentic" by Northerners. And thanks to her much improved Cantonese, she was able to well prepare her ACCA test by attending an on-line course which was only provided in Cantonese rather than putonghua.

\section{Are We Really Cantonese Speakers?}

My answer to the question is negative. The native speakers know we are not, and the non-native speakers know we are not. When one of my former teachers, who was a non-native but had been in Guangzhou for twenty years and Hong Kong for three years, spoke in Cantonese with other faculty workers, one classmate of mine giggled. When I greeted one student by a Cantonese pronunciation of her name, she responded, “Oh! Don’t humiliate my name." (in a half joking way of course). People easily tell non-native speakers from natives from pronunciation, tone, diction, etc. And why do we still speak the dialect sometimes? Are we really immersed in the language (and culture) and breathe easily? Do we want to stand out to show our different identity? Are we going to hurt others just like we were hurt years ago? Does the tolerance of use of Cantonese in class bring about a new round of discomfort to the new-comers to the city? ... These may be the questions I will focus on in the following study. At present, there is yet little conclusive remarks to make for this round of inquiry, for more data are needed, and the methodology may include not only autoethnography but life history of others and identity construction, which may help to explain the individual trilingualism.

\section{References}

Carolyn, E., \& Bochner, A. P. (2000). Autoethnography, Personal Narrative, Reflexivity: Researcher as Subject. In N. Denzin, \& Y. Lincoln (Eds.). The Handbook of Qualitative Research ( $2^{\text {nd }}$ Ed., pp. 733-768). Thousand Oaks, Ca.: Sage.

Feuerverger, G. (2007). Teaching, Learning and Other Miracles. Rotterdam: Sense Publishers. 